\title{
Long-term Holocene groundwater fluctuations in a chalk catchment: evidence from Rock-Eval pyrolysis of riparian peats
}

Andrew J. Newell ${ }^{1}$, Christopher H. Vane ${ }^{2}$, James P.R. Sorensen ${ }^{1}$, Vicky Moss-Hayes ${ }^{1}$ Daren C. Gooddy ${ }^{1}$

\author{
${ }^{1}$ British Geological Survey, Maclean Building, Wallingford, OX10 8BB, United Kingdom \\ ${ }^{2}$ British Geological Survey, Centre for Environmental Geochemistry, Keyworth, Nottingham, NG12 \\ $5 G G$, UK
}

\begin{abstract}
The depositional history of peat dominated wetlands can be used to understand palaeoclimate and paleohydrology, and also constrain the impacts of future climate change. However, in chalkland valleys seasonal water table fluctuations and a high alkalinity have decimated key environment indicators such as pollen and there is a need for alternative investigative techniques. The method of Rock-Eval pyrolysis can track changes in organic matter source and degradation, potentially relating to historic changes in vegetation cover. This was piloted on cores from a groundwater dependent riparian chalk valley wetland combined with radiocarbon dating. The dating showed that the cores represented approximately 4000 years of depositional history. Rock-Eval demonstrated significant changes in the normal alkane composition of the peat indicating shifts of around 500 to 1000 years between terrestrial and more aquatic species, relating to periods of climate wetness. These climatic shifts are broadly consistent with other evidence from ombrotrophic peatland and lacustrine sediments across northwest Europe. However, the connection between climate wetness and groundwater dependent chalkland wetlands is complicated by external anthropogenically-driven factors relating to land-use and vegetation cover changes in the catchment. Nonetheless this study suggests that Rock-Eval pyrolysis is a useful and cost-effective tool that can provide evidence for long-term Holocene groundwater fluctuations.
\end{abstract}

\section{Keywords}

Peat; Rock-Eval pyrolysis; Chalk; Groundwater; Lambourn; Climate change

\section{Introduction}

Chalkland rivers of southern England and northern France are predominantly fed by groundwater which can contribute more than $90 \%$ of the total baseflow (Griffiths et al., 2006). Groundwater level 
and river behaviour are thus intimately linked and the headwaters of chalk streams can move many kilometres up and down the catchment in response to changing groundwater level (Grapes et al., 2006). The development of densely-vegetated riparian wetlands in chalkland settings is similarly linked to groundwater input (House et al., 2015a, Grapes et al., 2006) and it is therefore possible that any accumulated peat profiles may contain some record of past groundwater levels in the catchment. An understanding of the timing and magnitude of groundwater fluctuations over past millennia is difficult to quantify, but is important not only in reconstructing palaeoclimate, palaeohydrogeology and palaeohydrology, but because it may help constrain predictions on how climate change will impact Chalk aquifers in the future (Jackson et al., 2011, Jimenez-Martinez et al., 2015).

Riparian peat deposits in northwest Europe may encompass many millennia, with many dating back to the start of the Holocene (11.7 cal kyr BP) when rapid global warming caused a switch from gravelly braided-river deposits of the Late Pleistocene cold stages to fine-grained and organic-rich floodplain deposits of the temperate Holocene (Macklin et al., 2010, Newell et al., 2015). However, while the length and continuity of the riparian peat record are potentially advantageous there are also problems, particularly in chalkland catchments, of peat degradation caused by seasonal water table fluctuation and high $\mathrm{pH}$, which can destroy key environmental indicators such as pollen (Waton, 1982). For example, in an examination of seventy peat cores from a chalkland valley at Winchester in Hampshire (UK) only one was found to be sufficiently polleniferous for analysis (Waton, 1982). Techniques which can determine changing sources of biomass and states of organic matter degradation, but which are independent of the need to retrieve identifiable pollen or plant macrofossils, are clearly desirable and are being increasingly applied in the use of peats as proxyclimate indicators (Chambers et al., 2012).

Rock-Eval pyrolysis is a geochemical screening technique typically applied to hydrocarbon bearing shales (Slowakiewicz et al., 2015) that has gained recent acceptance to track changes in organic matter source and degradation in unconsolidated sediments such as those in soils, lake sediments and coastal wetlands (Copard et al., 2006, Lacey et al., 2014, Engelhart et al., 2013a, Marchand et al., 2008, Khan et al., 2013). In this latter context, Rock-Eval parameters TOC, free hydrocarbons (S1), bound (polymeric) hydrocarbons (S2) describe the quantity and proportion of volatile hydrocarbons (S1) and cell wall biopolymers and there alteration products (S2). Whereas the hydrogen index (HI) values measure of the extent of organic matter hydrogenation as well as an indication of pre and post depositional alteration effects. Similarly, the oxygen index (OI) provides an estimate of the 
amount of oxygen containing compounds, a parameter that increases upon aerobic biological decay (Slowakiewicz et al., 2015), whereas Tmax values provides a means to estimate changes in organic matter type input since the maximum temperature at which bound hydrocarbons are cracked is related to the proportions of biopolymers (cellulose, xylans and phenolics such as lignin) and bonding between them (Marchand et al., 2008, Carrie et al., 2012). Normal alkanes ( $n$-alkanes) are a sub-class of wax lipid widely used to provenance organic matter in modern and lake and river sediments (Lamb et al., 2009, Meyers, 2003). Aquatic algae and plankton synthesise mainly odd numbered short-chain homologues $\left(C_{13}-C_{25}\right)$ maximising at about $C_{15}$ or $C_{17}$ in contrast vascular plants and particularly the waxy protective coatings of leaf cuticles biosynthesise mainly odd numbered long-chain homologues $\left(C_{23}-C_{35}\right)$ maximising at $C_{29}, C_{31}$ or $C_{33}$ (Eglinton and Hamilton, 1967, Cranwell, 1985). Although identification of a specific floral source may be confounded by the ubiquity of $C_{29}, C_{31}$ and $C_{33}$ in terrestrial systems Ficken et al., 2000 showed that submerged and floating leaved aquatic plants produce elevated abundances of $C_{23}$ and $C_{25}$ as compared to $C_{29}, C_{31}$ and $\mathrm{C}_{33}$ homologues. These compositional relationships are summarised by the aquatic proxy (Paq= $\left(\mathrm{C}_{23}+\mathrm{C}_{25}\right) /\left(\mathrm{C}_{23}+\mathrm{C}_{25}+\mathrm{C}_{29}+\mathrm{C}_{31}\right)$ to distinguish $n$-alkanes from plants that grow in terrestrial environment (Paq about 0.09), to those that are emergent (Paq about 0.25) to floating/ submerged (Paq $>0.50$ ) (Ficken et al., 2000, Filley et al., 2001, Lamb et al., 2009).

In this paper we test the utility of Rock-Eval pyrolysis as a means of tracking changing organic matter source within a riparian peat deposit from the River Lambourn in southern England. The Lambourn forms part of the River Thames catchment and is a typical northern European lowland chalk stream that over the past 15,000 years has moved from a periglacial, cold-climate setting to a temperate regime characterised by relatively steady stream-flow driven primarily by groundwater discharge (Newell et al., 2015). In the central part of the River Lambourn, riparian peats up to $2 \mathrm{~m}$ thick have accumulated at a long-lived wetland site at Boxford which date back to around 10,000 cal yr BP (Newell et al., 2015). In this paper we consider the organic geochemistry of the Boxford peats over the past 4000 years and discuss whether this provides any useful information on environmental change within the catchment. The paper contributes to the growing body of recent work in the Lambourn catchment, focussing particularly at the Boxford wetland site, aimed at understanding the hydrological and hydrogeological functioning of the chalkland catchment (Musgrave and Binley, 2011, Allen et al., 2010, Gooddy et al., 2006, House et al., 2015a, Grapes et al., 2006, Mullinger et al., 2007, Griffiths et al., 2006, Chambers et al., 2014, Newell et al., 2015). 


\section{Background to the River Lambourn}

\subsection{Modern river and catchment morphology}

The River Lambourn is a chalk stream in the Berkshire Downs of southern England. It rises near Lambourn and is a tributary of the River Kennet, which feeds into the River Thames (Grapes et al., 2006). The River Lambourn flows southeast down the regional slope of the Berkshire Downs, a gently tilted block of Cretaceous Chalk approximately $250 \mathrm{~m}$ thick which is incised by many valleys, the majority of which are dry with only a few containing perennial rivers. The Lambourn catchment is elongated in a NW-SE direction and is approximately $30 \mathrm{~km}$ long and $10 \mathrm{~km}$ wide, covering an area of $269 \mathrm{~km}^{2}$ with a mean elevation of $157 \mathrm{mAOD}$. The river has a perennial length of approximately 16 $\mathrm{km}$, and an upper seasonal section of around $7 \mathrm{~km}$ which exhibits characteristic bourne behaviour, where there is absence of flow for around three months of the year coincident with low groundwater levels, typically in late summer (Grapes et al., 2006). This is a predominantly groundwater-fed river with a mean flow of $1.73 \mathrm{~m}^{3} / \mathrm{s}$ and a baseflow index of 0.96 (Hannaford and Marsh, 2008). The modern River Lambourn is mainly a single thread channel typically around $5 \mathrm{~m}$ wide and $1.5 \mathrm{~m}$ deep which meanders across a narrow, confined floodplain typically around $200 \mathrm{~m}$ wide. The river splits into anastomosing channels in two anthropogenically-modified flood meadow areas at Welford and Boxford (Allen et al., 2010). The whole river is designated as a Site of Special Scientific Interest (SSSI) as it is a classic example of a lowland chalk river (Old et al., 2014).

\subsection{Catchment geology}

The Lambourn catchment is underlain by Cretaceous Chalk which dips at an angle of less than one degree toward the southeast. Across the northwest half of the Lambourn catchment, the Chalk has only a thin soil cover but in the southeast there are extensive Palaeogene and Quaternary siliciclastic deposits. There is no evidence for Quaternary glacial deposits in this part of southern England which throughout the cold climatic phases of the Pleistocene was located south of the overall glacial maximum under periglacial conditions (Ballantyne and Harris, 1994). River gravels of latest Pleistocene (Younger Dryas) age underlie the modern Lambourn floodplain and were deposited by rivers with a coarse bedload and strongly seasonal (nival) flow regimes. The gravels are sharply overlain by Holocene peats and chalky clays which are typically around 1-2 m thick (Newell et al., 2015, Chambers et al., 2014). Toward the valley margins Pleistocene fluvial gravels and Holocene alluvium interdigitate with poorly-sorted slope deposits (Newell et al., 2015).

\subsection{Boxford study site}


The study site $\left(51.44^{\circ} \mathrm{N}, 1.38^{\circ} \mathrm{W}\right)$ is located at a conspicuous bend in the Lambourn valley just to the north of Boxford (Figure 1). This Boxford site is a Special Area of Conservation (SAC) due to the habitat it provides for Desmoulins whorl snail (Vertigo moulinsiana) and is also as a SSSI because of its wetland habitats (Old et al., 2014). It has been the subject of much recent work aimed at understanding the functioning of the wetland (House et al., 2015a, House et al., 2015b) which has included the installation of boreholes (Newell et al., 2015, Allen et al., 2010) and geophysical surveys including electrical resistivity tomography (Chambers et al., 2014) and ground penetrating radar (Musgrave and Binley, 2011).

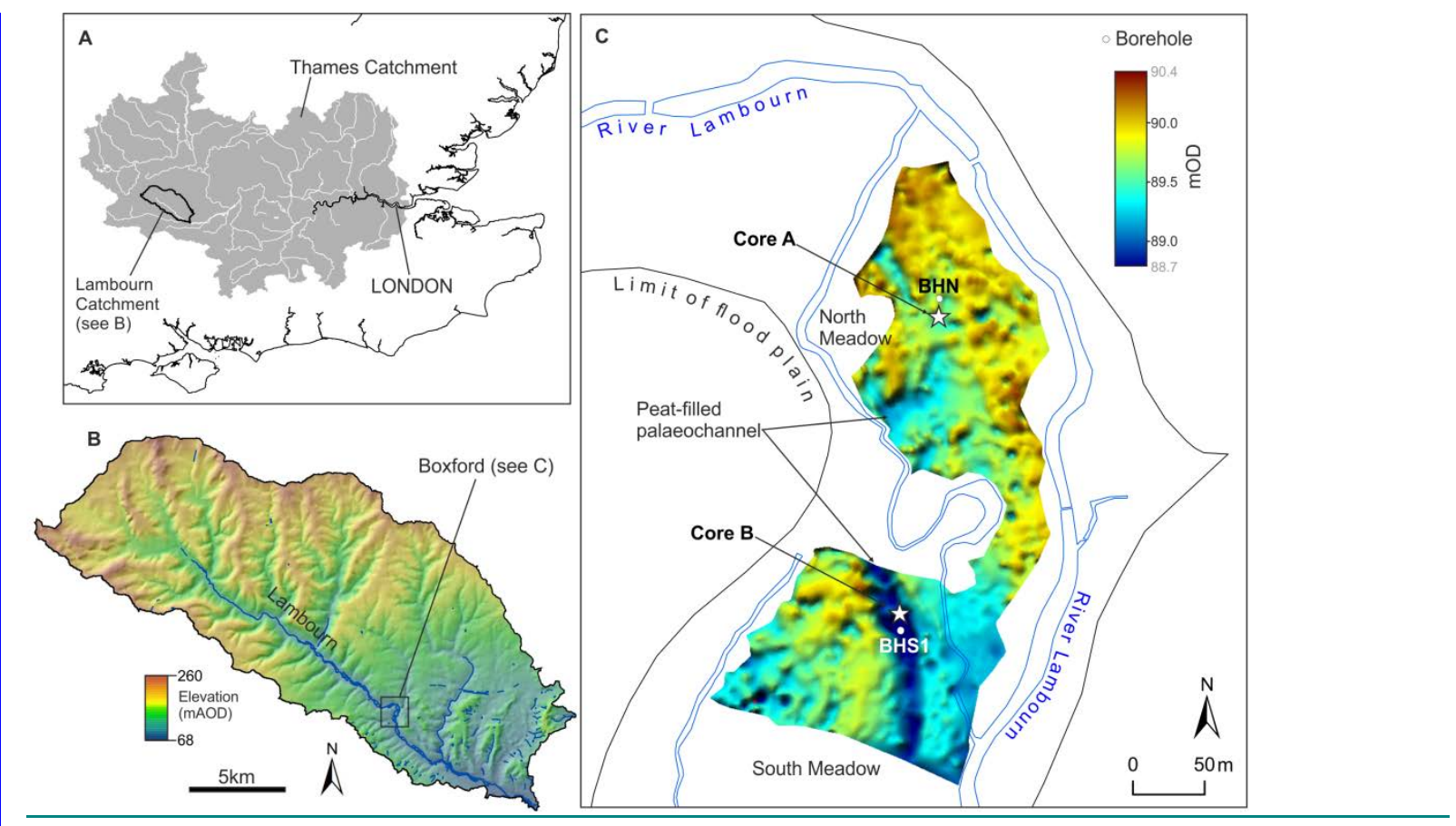

Beneath the densely-vegetated modern floodplain at Boxford is a layer of Holocene peat and clay which is typically around $1 \mathrm{~m}$ thick but locally up to $2 \mathrm{~m}$ thick where peats infill sinuous channels on the upper surface of the gravels (Newell et al., 2015, Chambers et al., 2014) (Figure 1). Radiocarbon dating of the deepest peats within channel fills showed that the peats at Boxford started to accumulate toward the beginning of the Holocene (9916-10117 cal yr BP) (Newell et al., 2015). By around 3932-4144 cal yr BP peat accumulation had expanded beyond the channels and was probably occurring across most of the floodplain. In the uppermost $1 \mathrm{~m}$ of the peats there is a general trend toward a reduction in Total Organic Carbon (TOC) which in some cores cumulates in a thin layer of pale brown chalky clay whose base is dated to around 332-513 cal yr BP (Figure 2).

Rock-Eval pyrolysis was undertaken on peat cores from two locations at the Boxford wetland. Core A was located in what is termed the North Meadow (adjacent to BHN of Chambers et al. (2014) and 
Newell et al. (2015)) and core B was located in the south meadow (adjacent to BHS1 of Chambers et al. (2014) and Newell et al. (2015)). Both cores were $1 \mathrm{~m}$ in length and acquired using a soil auger.

\section{Method}

\subsection{Rock-Eval6 Pyrolysis}

Sediments were analysed using a Rock-Eval(6) analyser configured in standard mode using a pyrolysis method identical to that previously used for salt marsh peats and lake sediments (Lacey et al., 2014, Engelhart et al., 2013b). Briefly, freeze dried, powdered samples (60 mg /dry wt) were heated from $300^{\circ} \mathrm{C}$ to $650^{\circ} \mathrm{C}$ at $25^{\circ} \mathrm{C} / \mathrm{min}$ in an inert atmosphere of $\mathrm{N}_{2}$ and the residual carbon then oxidised at $300^{\circ} \mathrm{C}$ to $850^{\circ} \mathrm{C}$ at $20^{\circ} \mathrm{C} / \mathrm{min}$ (hold $5 \mathrm{~min}$ ). Hydrocarbons released during the two-stage pyrolysis were measured using a flame ionization detector and $\mathrm{CO}$ and $\mathrm{CO}_{2}$ measured using an IR cell. Rock-Eval parameters were calculated by integration of the amounts of HC (thermally-vaporized free hydrocarbons) expressed in $\mathrm{mg} / \mathrm{HC} / \mathrm{g}$ rock (S1) and hydrocarbons released from cracking of bound $\mathrm{OM}$ expressed in $\mathrm{mg} / \mathrm{HC} / \mathrm{g}$ rock $(\mathrm{S} 2)$. The Hydrogen Index $(\mathrm{HI})$ was calculated from $\mathrm{S} 2 \mathrm{x}$ 100/TOC and the Oxygen Index (OI), S3 x 100/TOC (Slowakiewicz et al., 2015). Thermal maxima values (Tmax) were determined from the highest yield of bound hydrocarbons (S2). The performance of the instrument was checked every 8 samples against the accepted values of the Institut Français du Pétrole (IFP) standard (IFP 160 000, S/N1 5-081840) and instrumental error (standard deviation) was $\mathrm{S} 1 \pm 0.1 \mathrm{mg} \mathrm{HC} / \mathrm{g}$ rock, $\mathrm{S} 2 \pm 0.77 \mathrm{mg} \mathrm{HC} / \mathrm{g}$ rock, Total Organic $\mathrm{C} \pm 0.04 \% \mathrm{wt}$, Mineral $\mathrm{C} \pm 0.04 \% \mathrm{wt}$, $\operatorname{Tmax} \pm 1.4^{\circ} \mathrm{C}$.

\subsection{Gas Chromatography of saturate hydrocarbons}

Selected dried sediments $(0.5 \mathrm{~g})$ from cores A and B were each spiked with tetracosane-D50, squalane, hexatriacontane-D74 at 5 $\mathrm{g} / \mathrm{g}$ and allowed to equilibrate for $12 \mathrm{~h}$. Sediments were mixed with clean sand and copper powder and extracted dichloromethane/methanol $(9: 1 \mathrm{v} / \mathrm{v})$ at $75^{\circ} \mathrm{C}$ and 750 psi using an ASE. Extracts were reduced to dryness using a TurboVap and reconstituted in a minimum volume of dichloromethane/propan-2-ol $(2: 1 \mathrm{v} / \mathrm{v})$ for column chromatography. Silica gel (Si60 200-500 $\mu \mathrm{m}, 5 \%$ deactivated) was used in a $1.5 \times 20 \mathrm{~cm}$ column and eluted with three column volumes of $n$-hexane to isolate the saturate fraction. The eluent was reduced in volume $(1 \mathrm{~mL})$ and reconstituted in an appropriate volume of $n$-hexane for GC analysis. The saturates were analysed on a Hewlett Packard 6890 series GC-FID system fitted with an Agilent DB-1ms UI column (60m length, $0.25 \mathrm{~mm}$ id., $0.1 \mu$ film thickness). Oven temperature program was: $60^{\circ} \mathrm{C}$ (isothermal for 1 minute) to $320^{\circ} \mathrm{C}$ (isothermal for 15 minutes) at $10^{\circ} \mathrm{C} /$ minute. $1 \mu \mathrm{L}$ was injected at $280^{\circ} \mathrm{C}$ in splitless mode for 
$0.7 \mathrm{~min}$, split 1:10 thereafter. Helium carrier gas was $1 \mathrm{~mL} / \mathrm{min}$. Peak areas were integrated using Clarity software. Aquatic proxy (Paq) (Ficken et al., 2000)were determined using the quantified peak areas:

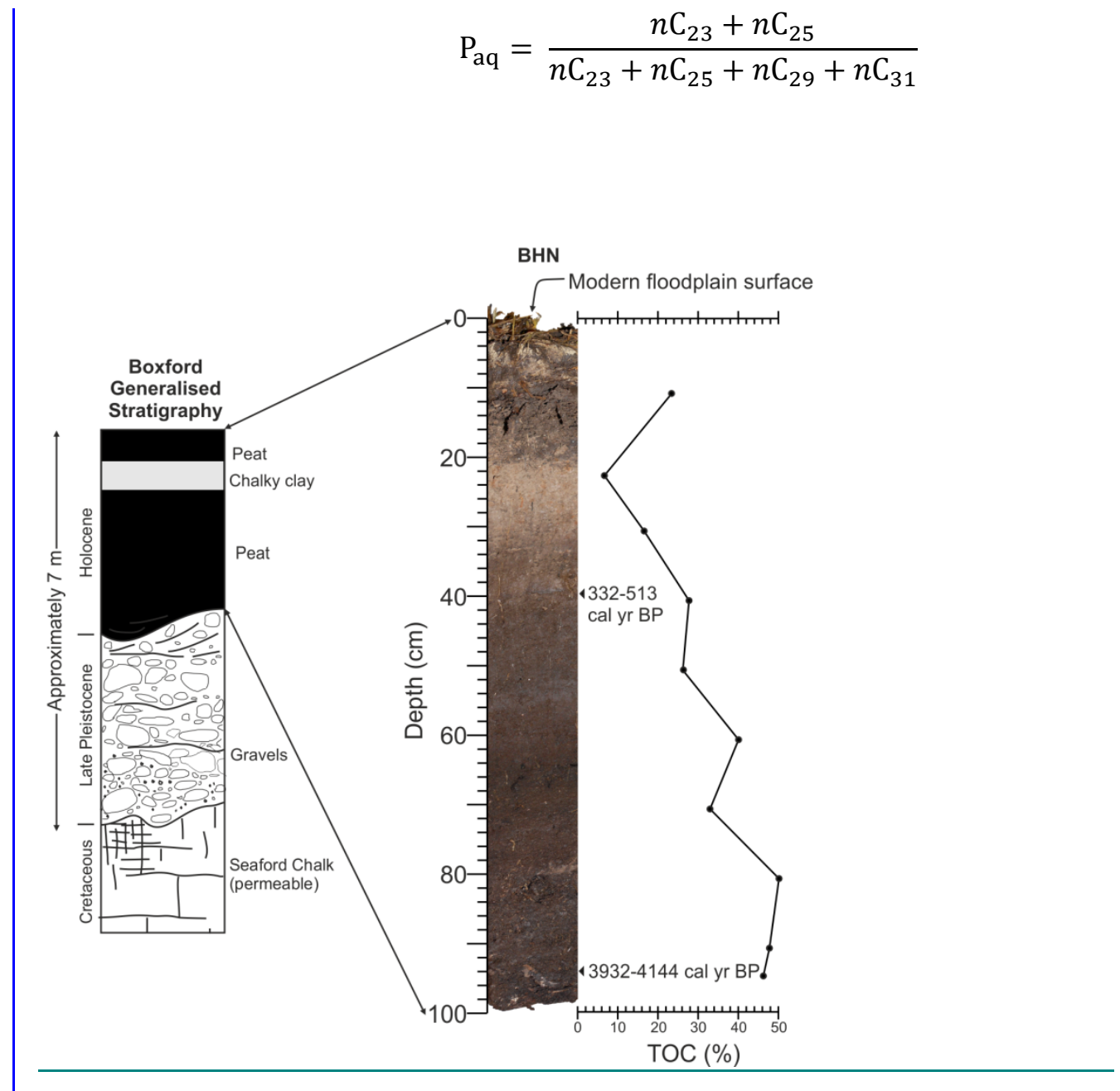

\section{Results \& Discussion}

\subsection{Bulk Geochemistry (Core A)}

High resolution Rock-Eval(6) parameters from Boxford core are shown in Figure 3. From the base of the core a systematic increase in TOC, S1 and S2 values is observed up to and including $62 \mathrm{~cm}$, this co-variance taken together with the gradual increasing in $\mathrm{HI}$ and later increase in Tmax values as well as the rather invariant \% mineral $\mathrm{C}$ (e.g. $\mathrm{CaCO}_{3}$ ) suggests two different organic matter sources. Previous Rock-Eval analysis of sediments from the oldest extant lake in Europe (Lake Ohrid) which accumulated mainly algal organic matter gave $\mathrm{HI}$ values 350 whereas those with a greater proportion of woody material yielded $\mathrm{HI}$ of 150 . At Boxford $(A)$ there is a step change from low $\mathrm{HI}$ 
values of 200 indicating more wood sourced organic matter to $~ 300$ which suggests a greater proportion of riverine (algal) organic matter.
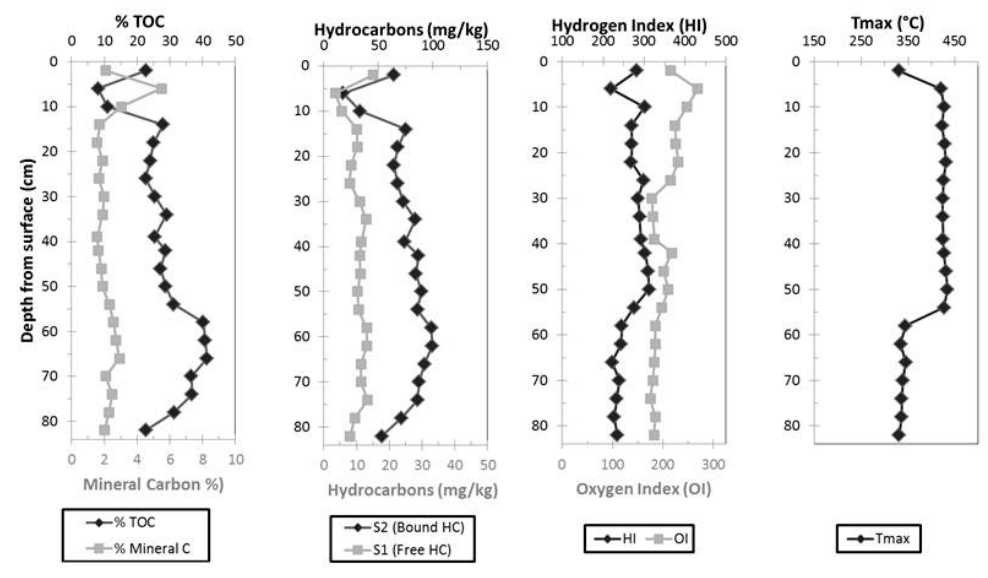

Inspection of the pyrograms from at $82 \mathrm{~cm}$ up to and including $62 \mathrm{~cm}$ show a distinct bimodal distribution within the $\mathrm{S} 2$ temperature range of 300 to $650^{\circ} \mathrm{C}$, characterised by a peak at a low pyrolysis temperature of $370^{\circ} \mathrm{C}$ (peak S2a), followed by a second lower abundance but rather broad higher temperature peak (peak S2b) at about $450^{\circ} \mathrm{C}$ (Figure 2). Conversely, sediments from above 62 $\mathrm{cm}\left(\right.$ e.g. $54 \mathrm{~cm}$ ) show a bimodal distribution with a maximal peak at the higher temperature of $475^{\circ} \mathrm{C}$ (Figure 4). One plausible explanation for these contrasting S2 peak forms is that the lower core interval $(82-62 \mathrm{~cm})$ is comprised of a greater proportion of organic with a moderate thermal stability such as lipids, proteins and carbohydrates whereas sediments from the higher core interval such as those above $62 \mathrm{~cm}$ are predominantly composed of organic matter with a high thermal stability such as lignin, tannin as well as their early diagenetic products formed by biotic and abiotic processes, 
humic substances (Hatcher and Clifford, 1994, Carrie et al., 2012).

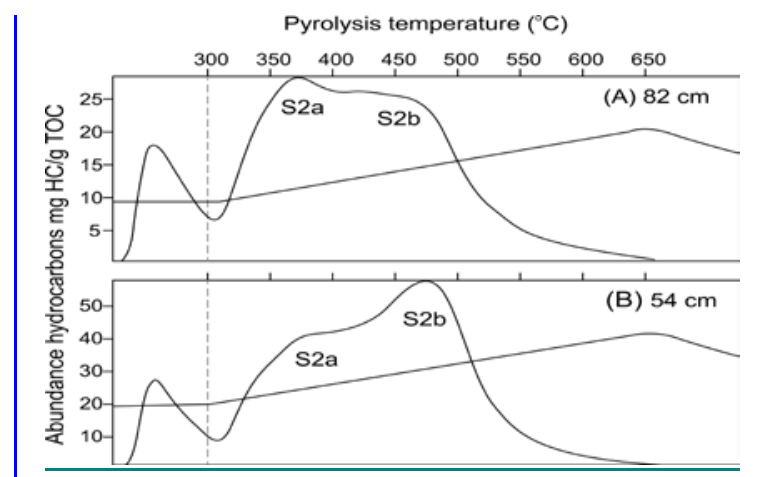

\subsection{Molecular Geochemistry (Core A)}

At Boxford (core A), sediments were analysed for $n$-alkanes, these were observed from $n \mathrm{C} 13$ to $n \mathrm{C} 35$ maximising in the $n \mathrm{C} 21$ to $n \mathrm{C} 33$ range (Figure 5). All sediments from Boxford core A showed a strong odd over even predominance which confirms a natural biological source as compared to hydrocarbons derived from anthropogenic (refined petroleum) or geogenic (crude oil) sources. From the base of the core ( 84 to $82 \mathrm{~cm}$ ) total alkane concentrations of $20-22 \mu \mathrm{g} / \mathrm{g}$ as well as pronounced Paq of 0.43 corresponding to $n$-alkane input from aquatic plants that are submerged/floating. This suggests either periodic waterlogging or even fully aquatic conditions prevailed long enough to allow deposition of either submerged, emergent and or fully aquatic plants.
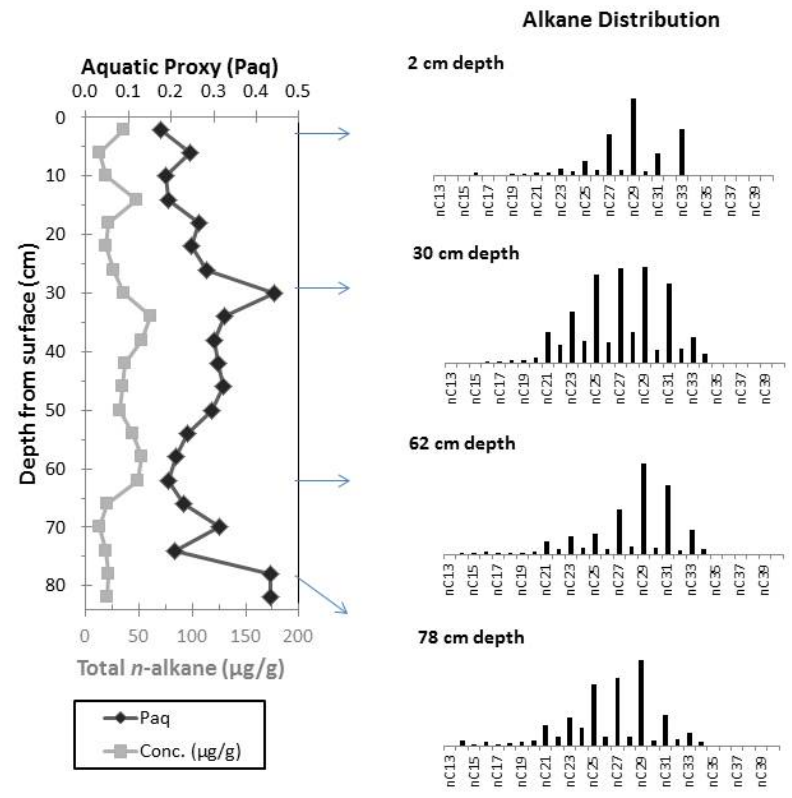
The stepped increase in $n$-alkane concentrations between $62 \mathrm{~cm}$ to $38 \mathrm{~cm}$ and a parallel decrease Paq to values ranging between 0.19 and 0.3 (Figure 5) indicates a switch to accumulation of mainly terrestrial organic matter. Inspection of the $n$-alkane profile at $62 \mathrm{~cm}$ depth (Figure 5) epitomises that from the leaves of land plants such as grasses and trees with a rather narrow composition maximised at $n \mathrm{C} 29$ and $n \mathrm{C} 31$ along with lesser amounts of $n \mathrm{C} 27$ and $n \mathrm{C} 33$. The $n$-alkane profiles from 62 up to $38 \mathrm{~cm}$ were rather invariant suggesting the same or similar terrestrial inputs throughout. However, the systematic increase in Paq profile from 58 up to and including $30 \mathrm{~cm}$ depth suggests a second phase of aquatic inundation reaching its maxima at $30 \mathrm{~cm}$ depth this notion is also supported by corresponding decrease in total alkane concentrations (Figure 5). Here, inspection of the of the $n$-alkane profile at $30 \mathrm{~cm}$ depth shows a broader range of alkanes ( $n \mathrm{C} 21-n \mathrm{C} 33$ ) which probably indicates a return to mainly terrestrial organic matter input from for example tree leaves and or grasses, for example the sample at $2 \mathrm{~cm}$ depth had the most terrestrial Paq of the entire Boxford core A profile of 0.17 . 
4.3 Bulk Geochemistry (Core B)
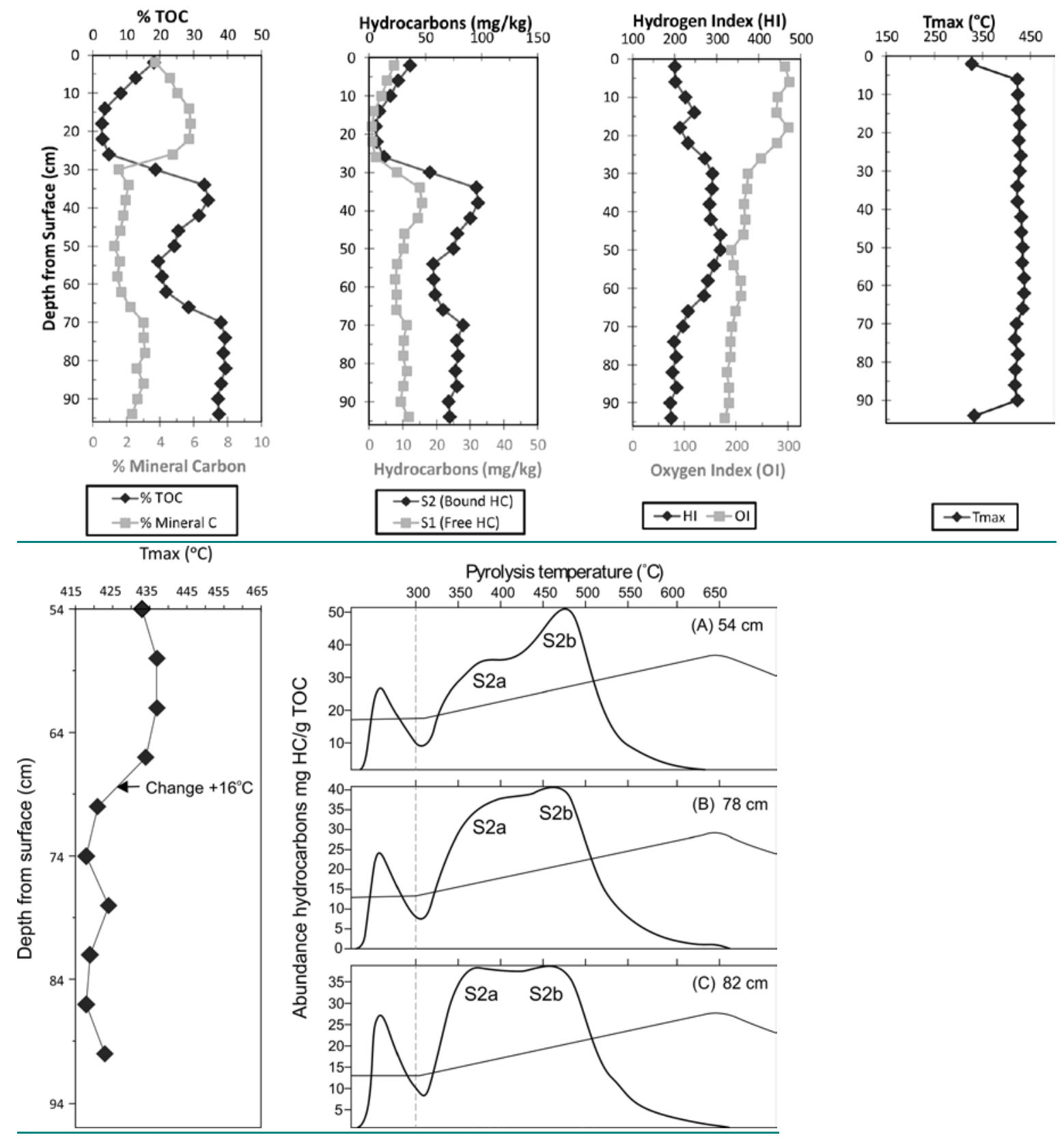

Selected Rock-Eval(6) parameters from Boxford core B are presented in (Figure 6). Taken together the TOC, S1, S2, $\mathrm{HI}$ and Ol suggest three changes in organic matter composition. Pyrograms from sediments within the lower portion of core Boxford KWB (90 cm up to $70 \mathrm{~cm}$ depth) show a bimodal distribution of bound hydrocarbons with equal S2a relative to S2b peaks (Figure 7). This suggests that the organic matter at the base of the core is comprised of a mixture of biopolymers including those of moderate thermal stability (Figure 5). Proceeding toward the surface, pyrograms from 66 $\mathrm{cm}$ and above display lower S2a peak intensity relative to S2b intensity (e.g. $54 \mathrm{~cm}$ Figure 7) which contrasts with underlying sediments and indicates greater thermal stability and confirms the $\mathrm{HI}$ based deduction that this corresponds to more lipid rich sources of organic matter (Figure 6). : A) 82 
$\mathrm{cm}$ depth from surface with a pronounced S2a suggesting lipid rich aquatic organic matter; B) 52 $\mathrm{cm}$ depth from surface showing moderate S2a and major S2b indicating greater contribution of complex structural biopolymers (e.g. polysaccharides, lignin, tannin).

\subsection{Molecular Geochemistry (Core B)}

Molecular level analyses of Boxford core B (0-94 cm depth) showed multiple phases of environmental change. The lowermost $94-90 \mathrm{~cm}$ depth interval yielded compositions dominated by $n C 27, n C 29$ and $n C 31$ and maximal at $n C 29$ (Figure 6). This together with the relatively high total alkane concentration of $40 \mu \mathrm{g} / \mathrm{g}$ and intermediate Paq of $0.25-0.31$ suggests accumulation of organic matter from terrestrial land plants as well as a possible contribution from emergent macrophytes. Moving up core, the decrease in total $n$-alkane concentrations and parallel increase in Paq centred at $58 \mathrm{~cm}$ depth together with the shift to a broader composition including greater amounts of the lower homologues $n \mathrm{C} 25$ and $n \mathrm{C} 27$ (Figure 7) probably indicates increased amount of alkanes sourced from emergent flora and or fully submerged floating flora, which suggests a switch to an environment subject to greater accumulation of aquatic organic matter. In contrast, sediments from $50 \mathrm{~cm}$ up to and including $26 \mathrm{~cm}$ gave lower Paq values ranging from 0.17 to 0.20 which when taken together with the homologue profiles dominated by $n \mathrm{C} 29$ and $n \mathrm{C} 31$ and to a lesser extent $n \mathrm{C} 27$ (see $n$-alkane profile at $42 \mathrm{~cm}$ as example) suggests the input and accumulation of terrestrial flora.

A final phase of aquatic influence is suggested at $20-22 \mathrm{~cm}$ depth with broad distribution of $n$ alkanes (e.g. $22 \mathrm{~cm}$ ) containing relatively greater amounts of lower homologues $n C 23, n C 25$ and $n$ C27 as well as $n$ C29 (Figure 8) than other depth intervals. This notion is also supported by the high Paq value of 0.37 which probably indicates a mixture of emergent (Paq about 0.25 ) and floating/ submerged $(\mathrm{Paq}>0.50)$ macrophytes. The greater proportion of even numbered $n$-alkanes $(n \mathrm{C} 24$, $n \mathrm{C} 26$ and $n \mathrm{C} 28$ ) probably indicates increased input from bacteria, since these have been shown to biosynthesise greater proportions of even numbered n-alkanes than plants (Peters et al., 2004). Finally, the uppermost intervals 2 to $6 \mathrm{~cm}$ depth suggest a return to greater terrestrial influence with intermediate Paq of 0.24 and $n$-alkane profiles dominated by the odd numbered higher homologues $n C 27, n C 29, n C 31$ and $n$ C33 as exemplified by the distribution profile at $2 \mathrm{~cm}$ (Figure 8). 


\section{Climate implications}

Rock Eval Pyrolysis of two peat cores from the River Lambourn floodplain at Boxford appear to indicate long-term alternations in peat surface wetness over the past 4000 years. Both cores provide evidence for three main episodes when aquatic flora (emergent to floating or submerged plants) predominated over terrestrial plants (Figure 9). It is possible, although not independently verified, that the wet and dry intervals correlate between the two core locations, which are separated by a horizontal distance of $232 \mathrm{~m}$ (Figure 9). There are clear differences in thickness between wet and dry intervals in each core, particularly toward the base where there appears to be a considerable expansion in core $\mathrm{B}$. This might be expected because core $\mathrm{B}$ represents only the upper part of a thicker (around $2 \mathrm{~m}$ ) peat succession which infills a channel while core A rests directly on gravels (Figure 1). Compression of underlying peats could generate additional space to accommodate thicker intervals in core B. Radiocarbon dating of a borehole (BHN) adjacent to core A (Newell et al., 2015) showed that $550 \mathrm{~mm}$ of peat accumulated between 3932-4144 cal yr BP and 332-513 cal yr BP (Figure 2). Taking a mid-point in these calibrated age ranges and taking no account of compaction yields an accumulation rate of around $0.15 \mathrm{~mm} \mathrm{yr}^{-1}$. Individual wet and dry intervals within each core vary greatly in thickness but most are broadly in the order of 500 to 1000 years in duration. Above a depth of $400 \mathrm{~mm}$ there is acceleration in the deposition rate to around $1 \mathrm{~mm} \mathrm{yr}{ }^{-1}$ which is associated with a fall in the TOC, an increase in the proportion of chalky clays (Figure 2) and in both cores A and $B$ a trend toward terrestrial Paq values. The influx of chalky clay and accelerated deposition rate from around $400 \mathrm{yr} \mathrm{BP}$ is probably related to changing agricultural practise within the catchment (Newell et al., 2015). In many river catchments in Britain there is strong evidence for accelerated floodplain accretion from around $1000 \mathrm{yr}$ BP related to the Medieval agricultural revolution with widespread land clearance and ploughing (Lewin, 2010). 

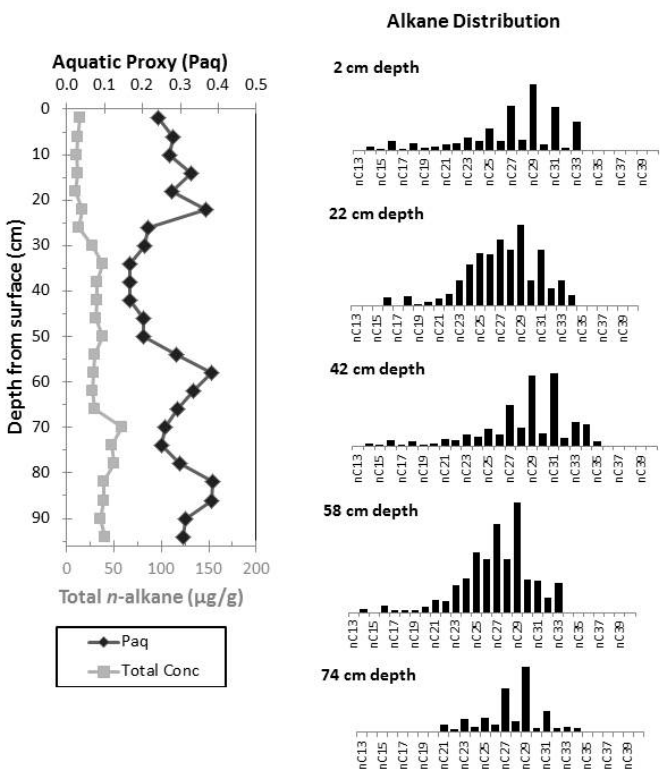

A cyclical variation in the relative wetness of peatland surfaces has long been recognised in the peat stratigraphies of northwest Europe, initially through the alternation of light-coloured (well humified) and dark-coloured (weakly humified) peats (Granlund, 1932), but more recently through many other wetness indicators including pollen, plant macrofossils, geochemical biomarkers, dust flux and testate amoebae (Chambers et al., 2012). The majority of work has been undertaken on ombrotrophic peatlands, raised mires which receive all of their water from precipitation rather than from streams or springs. In ombrotrophic peatlands the link between atmospheric climate and precipitation is more direct than in, for example, valley mires which are fed by groundwater. Although not universally accepted, the stratigraphy of ombrotrophic peatlands appears to show a reasonably clear link between fluctuations in peatland surface wetness and climate change, particularly on centennial to millennial timescales (Chambers et al., 2012, Langdon et al., 2012). A synthesis of peatland records for northern Britain, where many of the raised mires suitable for palaeoclimate reconstruction are found, indicated pronounced changes to wet conditions at 3600 , 2760 and 1600 cal yr BP with more minor changes at 3060, 2050, 1260, 860, 550 and 260 cal yr BP (Charman et al., 2006). The main wet phases are highly correlated with mid-European lake highstands, wider North Atlantic climate change inferred from ocean and ice core records, and solar variability (Charman et al., 2006). 


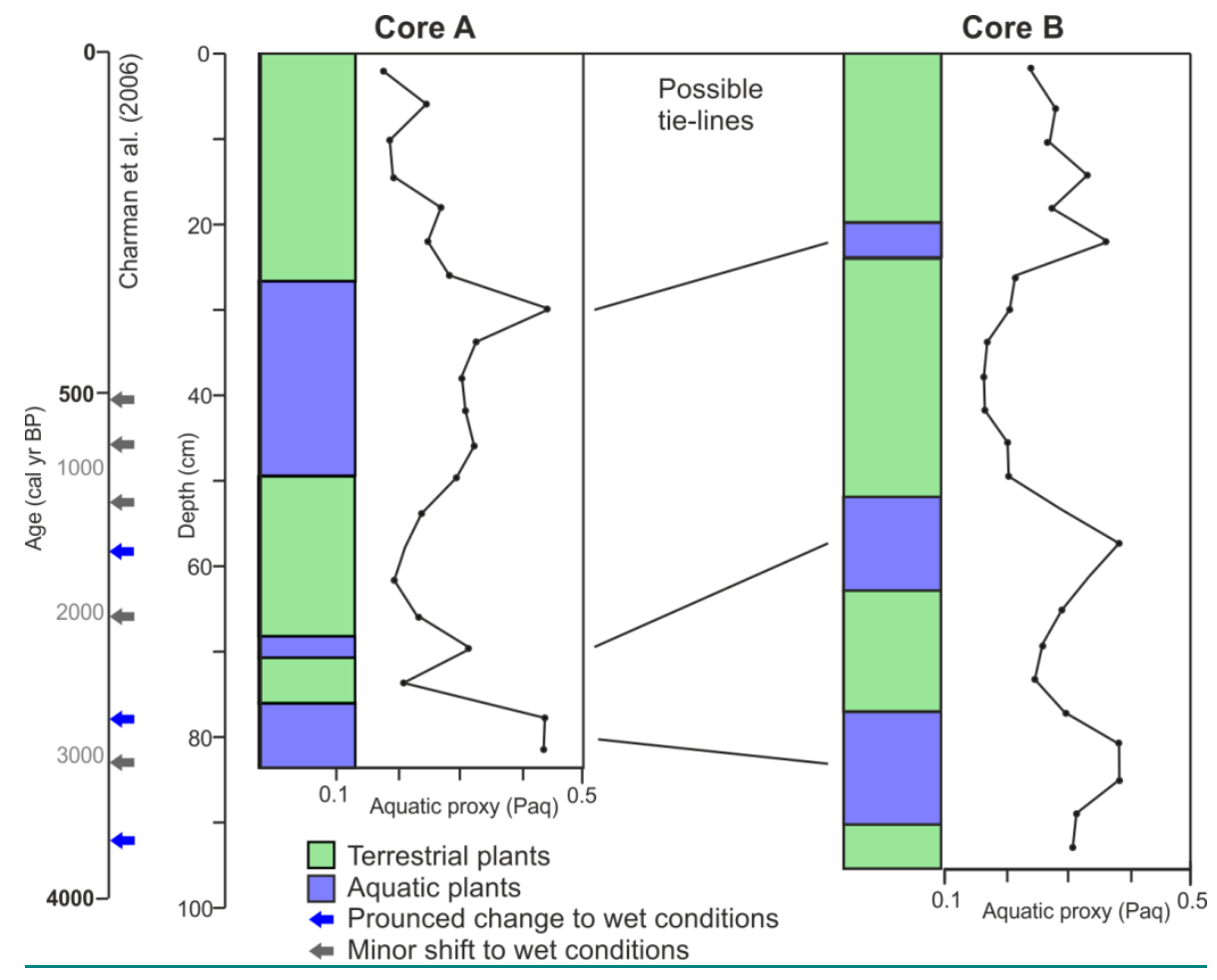

The riparian peats under discussion in this paper clearly differ from the ombrotrophic peatlands of northern Britain in that they are dominated by groundwater input from permeable Chalk aquifers rather than direct precipitation (House et al., 2015a). Precipitation falling within the Chalk catchment typically infiltrates the aquifer on broad, elevated interfluves before moving vertically through the unsaturated zone and laterally toward discharge points along river valleys (Figure 10). A direct correlation between wet climatic phases such as those determined by Charman et al. (2006) and shifts in the surface wetness of chalkland riparian peats might not be expected because precipitation is only one of several controls on groundwater levels. Modelling studies showing the importance of variations in land-use and associated vegetation type on potential groundwater recharge within the chalkland catchments of southern Britain (Jackson et al., 2011). 


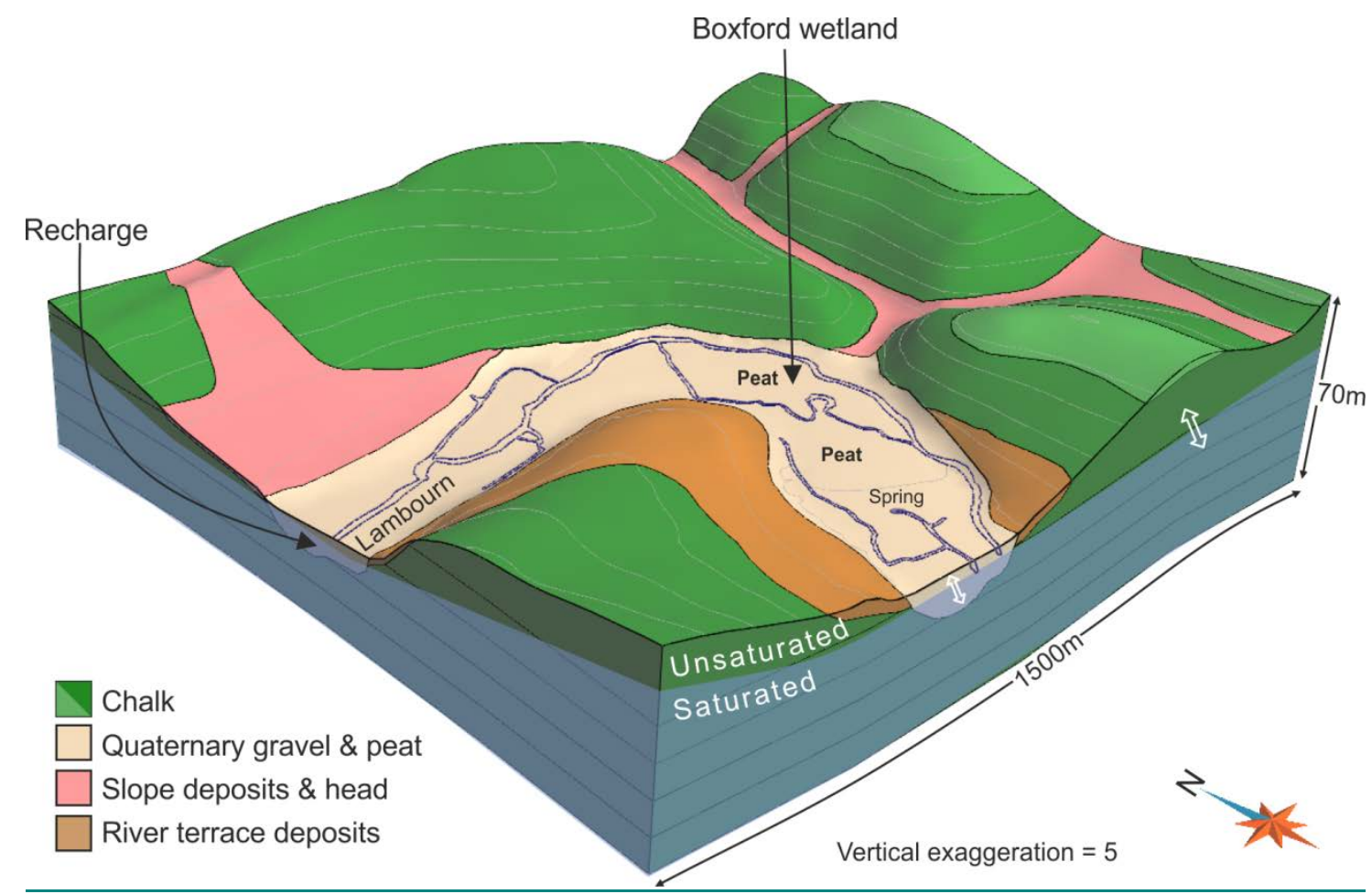

Particularly in the last 5000 years there have been major changes in land-use and vegetation cover related to anthropogenic land clearance and agricultural activity. Pollen analysis from interfluve areas of the Lambourn catchment shows a general trend of forest clearance and the expansion of grassland and cereals over the past 4000 years (Waton, 1982). It is therefore possible that fluctuations in the surface wetness of groundwater-fed mires in the Lambourn over the past 4000 years result not only from changes in climate, with periodic shifts toward wetter conditions on an approximate time interval of 500-1000 years (Charman et al., 2006), but of changes in groundwater recharge related to vegetation clearance and land-use change. Direct intervention in the degree of floodplain wetness arising from factors such as beaver activity, log jams and anthropogenic modification also need to be considered (Collins et al., 2006) as do autogenic cycles in the growth and accumulation of peats (Korhola, 1996).

\section{Conclusions}

- Determining long-term variation in peat surface wetness in chalkland settings is problematic because groundwater fluctuations and high $\mathrm{pH}$ cause a degradation of normal proxies such as pollen (Waton, 1982).

- Rock-Eval pyrolysis may discriminate long-term variations in the relative wetness of the peatland surface through the identification of biomarkers for aquatic and terrestrial plants.

- Studies from two metre-long cores (located $232 \mathrm{~m}$ apart) show comparable alternating intervals dominated by aquatic and terrestrial vegetation. Radiocarbon dating shows that 
each core represents approximately 4000 years suggesting fluctuations in surface wetness over periods of around 500 to 1000 years.

- Evidence from ombrotrophic peatland and lacustrine sediments across northwest Europe show evidence for multiple shifts in climate wetness over the past 4000 years on a broadly comparable time-frame to those described here (Charman et al., 2006). However, the link between climate wetness and chalkland groundwater-fed mires may not be entirely straightforward because of the potential importance of anthropogenically-driven changes in land-use and vegetation cover within the Lambourn catchment.

- Rock-Eval pyrolysis does provide evidence for long-term Holocene groundwater fluctuations.

\section{Acknowledgements}

This paper is published with permission of the Executive Director of the British Geological Survey (NERC).

\section{Figure Captions}

Figure 1. (A) Location of the Lambourn catchment within the Thames catchment, (B) Elevation of the Lambourn catchment and location of the study site at Boxford, (C) Detailed map of the Boxford study showing the location of core A and B discussed in the text and the elevation of the sub-peat surface showing the location of channels on the underlying gravel.

Figure 2. Generalised Quaternary stratigraphy at Boxford showing Holocene peats and chalky clays resting on Late Pleistocene gravels. Core photograph (BHN, see Figure 1 for location) enlarges the Holocene peat-dominated succession and shows the position of two radiocarbon dates and a TOC curve.

Figure 3. Down-profile changes in Boxford core A organic matter using Rock-Eval pyrolysis.

Figure 4. Rock-Eval(6) pyrograms of sediments from Boxford KW1: A) $82 \mathrm{~cm}$ depth from surface with a pronounced S2a suggesting lipid rich aquatic organic matter; B) $54 \mathrm{~cm}$ depth from surface showing moderate S2a and major S2b indicating greater contribution of complex structural biopolymers (e.g. polysaccharides, lignin, tannin).

Figure 5. Molecular level changes (normal alkanes) in Boxford core A; Contrasting exemplar distributions interpreted to indicate mainly terrestrial $(62 \mathrm{~cm})$ as compared to mixed aquatic/emergent $(30 \mathrm{~cm})$.

Figure 6. Down-profile changes in Boxford core B organic matter using Rock-Eval pyrolysis 
Figure 7. Rock-Eval(6) pyrograms and expanded Tmax profile of sediments from Boxford KW2. The pyrograms confirm a change in organic matter source as indicated by variation in the proportion of S2a as compared to S2b peak. Combined this suggests change from less to more thermally stable organic matter across $70 \mathrm{~cm}$ to $66 \mathrm{~cm}$ depth interval.

Figure 8. Molecular level changes (normal alkanes) in Boxford core B; Contrasting exemplar distributions interpreted to indicate mainly terrestrial (e.g. 2, 42, $74 \mathrm{~cm}$ ) as compared to mixed aquatic/emergent (e.g. $22,58 \mathrm{~cm})$.

Figure 9. Summary diagram showing cycles of aquatic- and terrestrial-dominated vegetation cycles in cores A and B. Age scale is based on linear interpolation of two radiocarbon dates (shown in bold) of borehole BHN (Newell et al., 2015) immediately adjacent to core A. Pronounced and minor shifts in climate wetness over the interval 500-4000 cal yr BP are from Charman et al. (2006).

Figure 10. Simplified geological block model of the Boxford site showing how groundwater is connected to valley peat mires in the permeable chalk catchment.

\section{References}

ALLEN, D., DARLING, W. G., GOODDY, D., LAPWORTH, D., NEWELL, A., WILLIAMS, A., ALLEN, D. \& ABESSER, C. 2010. Interaction between groundwater, the hyporheic zone and a Chalk stream: a case study from the River Lambourn, UK. Hydrogeology Journal, 18, 1125-1141.

BALLANTYNE, C. K. \& HARRIS, C. 1994. The periglaciation of Great Britain, Cambridge., C.U.P.

CARRIE, J., SANEI, H. \& STERN, G. 2012. Standardisation of Rock-Eval pyrolysis for the analysis of recent sediments and soils. Organic Geochemistry, 46, 38-53.

CHAMBERS, F. M., BOOTH, R. K., DE VLEESCHOUWER, F., LAMENTOWICZ, M., LE ROUX, G., MAUQUOY, D., NICHOLS, J. E. \& VAN GEEL, B. 2012. Development and refinement of proxyclimate indicators from peats. Quaternary International, 268, 21-33.

CHAMBERS, J. E., WILKINSON, P. B., UHLEMANN, S., SORENSEN, J. P. R., ROBERTS, C., NEWELL, A. J., WARD, W. O. C., BINLEY, A., WILLIAMS, P. J., GOODDY, D. C., OLD, G. \& BAI, L. 2014. Derivation of lowland riparian wetland deposit architecture using geophysical image analysis and interface detection. Water Resources Research, 50, 5886-5905.

CHARMAN, D. J., BLUNDELL, A., CHIVERRELL, R. C., HENDON, D. \& LANGDON, P. G. 2006. Compilation of non-annually resolved Holocene proxy climate records: Stacked Holocene peatland palaeo-water table reconstructions from northern Britain. Quaternary Science Reviews, 25, 336-350.

COLLINS, P. E. F., WORSLEY, P., KEITH-LUCAS, D. M. \& FENWICK, I. M. 2006. Floodplain environmental change during the Younger Dryas and Holocene in Northwest Europe: Insights from the lower Kennet Valley, south central England. Palaeogeography, Palaeoclimatology, Palaeoecology, 233, 113-133.

COPARD, Y., DI-GIOVANNI, C., MARTAUD, T., ALBRECH, P. \& OLIVIER, J.-E. 2006. Using Rock Eval 6 pyrolysis for tracking fossil organic carbon in modern environments: implications for the roles of errosion and weathering. Earth Surface Processes and Landforms, 31, 135-153.

CRANWELL, P. A. 1985. Long-Chain Unsaturated-Ketones in Recent Lacustrine Sediments. Geochimica Et Cosmochimica Acta, 49, 1545-1551.

EGLINTON, G. \& HAMILTON, J. 1967. Leaf epicuticular waxes. Science, 156, 1322-1335. 
ENGELHART, S. E., HORTON, B. P., NELSON, A. R., HAWKES, A. D., WITTER, R. C., WANG, K., WANG, P.-L. \& VANE, C. H. 2013a. Testing the use of microfossils to reconstrut great earthquakes at Cascadia. Geology, 41, 1067-1070.

ENGELHART, S. E., HORTON, B. P., VANE, C. H., NELSON, A. R., WITTER, R. C., BRODY, S. R. \& HAWKES, A. D. 2013b. Modern foraminifera, $\delta 13 \mathrm{C}$, and bulk geochemistry of central Oregon tidal marshes and their application in paleoseismology. Palaeogeography, Palaeoclimatology, Palaeoecology, 377, 13-27.

FICKEN, K. J., LI, B., SWAIN, D. L. \& EGLINTON, G. 2000. An $n$-alkane proxy for the sedimentary input of submerged/ floating freshwater aquatic macrophytes. Organic Geochemistry, 31, 745749.

FILLEY, T. R., FREEMAN, K. H., BIANCHI, T. S., BASKARAN, M., COLARUSSO, L. A. \& HATCHER, P. G. 2001. An isotopic biogeochemical assessment of shifts in organic matter input to Holocene sediments from Mud Lake, Florida. Organic Geochemistry, 32, 1153-1167.

GOODDY, D. C., DARLING, W. G., ABESSER, C. \& LAPWORTH, D. J. 2006. Using chlorofluorocarbons (CFCs) and sulphur hexafluoride (SF6) to characterise groundwater movement and residence time in a lowland Chalk catchment. Journal of Hydrology, 330, 44-52.

GRANLUND, E. 1932. De svenska högmossarnas geologi. Sveriges Geologiska Undersökningar C 373. Årsbog 26, 1e193.

GRAPES, T. R., BRADLEY, C. \& PETTS, G. E. 2006. Hydrodynamics of floodplain wetlands in a chalk catchment: The River Lambourn, UK. Journal of Hydrology, 320, 324-341.

GRIFFITHS, J., BINLEY, A., CROOK, N., NUTTER, J., YOUNG, A. \& FLETCHER, S. 2006. Streamflow generation in the Pang and Lambourn catchments, Berkshire, UK. Journal of Hydrology, 330, 71-83.

HATCHER, P. G. \& CLIFFORD, D. J. 1994. Flash pyrolysis and in-situ methylation of humic acids from soil. Organic Geochemistry, 21, 1081-1092.

HOUSE, A., SORENSEN, J. R., GOODDY, D., NEWELL, A., MARCHANT, B., MOUNTFORD, J. O., SCARLETT, P., WILLIAMS, P. \& OLD, G. 2015a. Discrete wetland groundwater discharges revealed with a three-dimensional temperature model and botanical indicators (Boxford, UK). Hydrogeology Journal, 1-13.

HOUSE, A., THOMPSON, J., SORENSEN, J., ROBERTS, C. \& ACREMAN, M. 2015b. Modelling groundwater/surface water interaction in a managed riparian chalk valley wetland. Hydrological Processes.

JACKSON, C. R., MEISTER, R. \& PRUDHOMME, C. 2011. Modelling the effects of climate change and its uncertainty on UK Chalk groundwater resources from an ensemble of global climate model projections. Journal of Hydrology, 399, 12-28.

JIMENEZ-MARTINEZ, J., SMITH, M. \& POPE, D. 2015. Prediction of groundwater-induced flooding in a chalk aquifer for future climate change scenarios. Hydrological Processes.

KHAN, N. S., HORTON, B. P., MCKEE, K. L., JEROLMACK, D., FALACINI, F., ENACHE, M. D. \& VANE, C. H. 2013. Tracking sedimentation from the historic A.D. 2011 Mississippi River flood in the deltaic wetlands of Louisinana, USA. Geology, 41, 391-394.

KORHOLA, A. 1996. Initiation of a sloping mire complex in southwestern Finland: Autogenic versus allogenic controls. Ecoscience 3, 216-222.

LACEY, J. H., FRANCKE, A., LENG, M. J., VANE, C. H. \& WAGNER, B. 2014. A high-resolution Late Glacial to Holocene record of environmental change in the Mediterranean from Lake Ohrid (Macedonia/Albania). International Journal of Earth Sciences, 1-16.

LAMB, A. L., GONZALEZ, S., HUdDART, D., METCALFE, S. E., VANE, C. H. \& PIKE, A. W. G. 2009. Tepexpan Palaeoindian site, Basin of Mexico: multi-proxy evidence for environmental change during the late Pleistocene-late Holocene. Quaternary Science Reviews, 28, 20002016. 
LANGDON, P. G., BROWN, A. G., CASELDINE, C. J., BLOCKLEY, S. P. E. \& STUIJTS, I. 2012. Regional climate change from peat stratigraphy for the mid- to late Holocene in central Ireland. Quaternary International, 268, 145-155.

LEWIN, J. 2010. Medieval environmental impacts and feedbacks: The lowland floodplains of England and Wales. Geoarchaeology, 25, 267-311.

MACKLIN, M. G., JONES, A. F. \& LEWIN, J. 2010. River response to rapid Holocene environmental change: evidence and explanation in British catchments. Quaternary Science Reviews, 29, 1555-1576.

MARCHAND, C., LALLIER-VERGÈS, E., DISNAR, J. R. \& KÉRAVIS, D. 2008. Organic carbon sources and transformations in mangrove sediments: A Rock-Eval pyrolysis approach. Organic Geochemistry, 39, 408-421.

MEYERS, P. A. 2003. Applications of organic geochemistry to paleolimnological reconstructions: a summary of examples from the Laurentian Great Lakes. Organic Geochemistry, 34, 261-289.

MULLINGER, N. J., BINLEY, A. M., PATES, J. M. \& CROOK, N. P. 2007. Radon in Chalk streams: Spatial and temporal variation of groundwater sources in the Pang and Lambourn catchments, UK. Journal of Hydrology, 339, 172-182.

MUSGRAVE, H. \& BINLEY, A. 2011. Revealing the temporal dynamics of subsurface temperature in a wetland using time-lapse geophysics. Journal of Hydrology, 396, 258-266.

NEWELL, A. J., SORENSEN, J. P. R., CHAMBERS, J. E., WILKINSON, P. B., UHLEMANN, S., ROBERTS, C., GOODDY, D. C., VANE, C. H. \& BINLEY, A. 2015. Fluvial response to Late Pleistocene and Holocene environmental change in a Thames chalkland headwater: the Lambourn of southern England. Proceedings of the Geologists' Association.

PETERS, K. E., WALTERS, C. C. \& MOLDOWAN, J. M. 2004. The biomarker guide volume 2, Cambridge, Cambridge University Press.

SLOWAKIEWICZ, M., TUCKER, M., VANE, C. H., HARDING, R., COLLINS, A. \& PANCOST, R. D. 2015. Shale-gas potential of the mid-Carboniferous Bowland-Hodder unit in the Cleveland basin (Yorkshire), Central Britain. Journal of Petroleum Geology, 38, 1-18.

WATON, P. V. 1982. Man's impact on the chalklands: some new pollen evidence. In: BELL, M. \& LIMBREY, S. (eds.) Archaeological Aspects of Woodland Ecology. Oxford: British Archaeological Reports International Series 146. 